\title{
Outsourcing from the perspectives of TCE and RBV: A multiple case study
}

\author{
Lincoln Wolf de Almeida Neves ${ }^{\mathrm{a}}$, Silvio Hamachera, Luiz Felipe Scavarda ${ }^{\mathrm{c} *}$ \\ alwaneves@uninet.com.br, PUC-Rio, Brasil \\ bhamacher@puc-rio.br, PUC-Rio, Brasil \\ c*If.scavarda@puc-rio.br, PUC-Rio, Brasil
}

\begin{abstract}
The theories of transaction cost economics (TCE) and the resource-based view (RBV) have been applied in studies of outsourcing. The research presented in this study was conducted to gain an understanding of why firms outsource their value chain activities, using a combined TCE and RBV perspective. The research assesses how six instant coffee firms in Brazil perceive the rationale for their outsourcing processes. The authors conclude that the two theories should be used together to determine a firm's frontiers, and they offer a mechanism for combining them. The results, relevant to both academics and practitioners, reveal that outsourcing should be defined at two stages: an initial strategic stage in which the activities that should be performed internally are identified, based on RBV, and a second stage in which the activities that can be performed externally are examined and those that should be outsourced are identified on the basis of both TCE and RBV. Insights relevant to practitioners include the importance of the executive leadership role in defining a firm's outsourcing strategy and the need for constant vigilance to prevent opportunism in relationships with trading partners.
\end{abstract}

Keywords

Outsourcing. Transaction cost economics. Resource-based view. Instant coffee.

\section{Introduction}

In order for firms to define their corporate strategies, they must analyze their competitive scope, which is composed of three major dimensions: product scope, geographic scope, and vertical scope (PORTER, 1985; GRANT, 2005). This paper is focused on the latter of these three, determining which activities should be internally performed within firms (vertical integration) and which should be performed by external suppliers (outsourcing). Following Mclvor (2005), outsourcing is defined in this study as the sourcing of goods and services previously produced internally within the sourcing organization from external suppliers.

The decision regarding which operations should be carried out internally and which should be performed by suppliers is crucial to the competitiveness of firms (VENKATESAN, 1992; BECKMAN; ROSENFIELD, 2008; DABHILKAR; BENGTSSON, 2008; ELLRAM; TATE; BILLINGTON, 2008). Two major research lines were developed to address this issue: first, the Transaction Cost Economics (TCE) theory and, next, the Resource Based View (RBV).

The TCE theory was developed through the exceptional contributions of Economics Nobel Laureates R. Coase and O. E. Williamson. Coase (1937) notes that firms, to buy a product or service, incur some costs. These include price searching, provider searching, negotiation, and contracting and are termed transaction costs. For Coase (1937), firms and markets are alternative forms of organization to manage the same transactions, and the choice of where to carry out these transactions influences their efficiency. Based on an analysis of the magnitude of these costs, entrepreneurs decide where the transactions should occur, either within the firms or in the market. Later, Williamson $(1979,1985)$ extended Coase's studies to include additional upcoming transaction costs: the information asymmetry between parties while 
transacting and the principle that every human being has limited rationality.

The modern RBV was developed in 1984 through the work of Wernerfelt (1984) and Rumelt (1984). The RBV proposes that firms should compare their skills with those of the markets and other firms and should not outsource core competencies or competencies involving special skills or strategies (PRAHALAD; HAMEL, 1990; QUINN; HILMER, 1994; FINE, 1998).

Although TCE theory is used widely (BARNEY; CLARK, 2007), the results of outsourcing recommended by TCE are not always confirmed, presenting anomalies and insufficiencies when determining firms' boundaries (HOLMSTRON; ROBERTS, 1998; POPPO; ZENGER, 1998; WILLIAMSON, 1999). To overcome these limitations, several academic papers have indicated recently that the study of outsourcing should consider both the TCE and RBV theories (MAYER; SALOMON, 2006; HOLCOMB; HITT, 2007, VERWAAL; COMMANDEUR; VERBEKE, 2009), addressing a former existing gap in the literature. However, these studies do not offer clearly mechanisms to combine both theories, thereby establishing an important gap to be addressed in future studies.

Within this context, the goal of this paper is to understand, using a combined TCE and RBV perspective, the reasons why firms outsource activities in their value chain, determining the key drivers of outsourcing and the context in which these drivers are defined. This research is based on an empirical study of six firms in the instant coffee industry in Brazil, focusing on the rationale for their outsourcing processes.

The main contribution of this paper is the offer of a mechanism to combine both theories for the outsourcing decision with a two-stage approach: the first stage is based on the RBV theory and involves identification of core competences or resources that lead firms to competitive advantage, which should be vertically integrated; in the second stage, both TCE and RBV theories are combined to assess all transactions that could be outsourced, considering transaction-specific investment and uncertainties, as well as strengths and weaknesses of both the firm and the supplier market. Additionally, this research explores more how the outsourcing decision should be defined combining these two theories within the operations management context, addressing an important concern highlighted in Holcomb and Hitt (2007) and Mclvor $(2009,2013)$. Both TCE and RBV theories focus on important concerns for operations management scholars, including the development and leveraging of capabilities for competitive advantage, and an understanding of where it is appropriate to pursue efficiencies and where it is appropriate to pursue collaborative relations with suppliers (McIVOR, 2009). As a result, this research also makes a contribution to an area that has received limited attention from operations management scholars.

This study is organized into six sections, with the first being this introduction. The second section presents a literature review on the TCE and RBV theories. The third section presents the research method, while the fourth section characterizes the context of instant coffee firms in Brazil. The fifth section presents a comparative analysis between cases from the perspective of the TCE and RBV theories. Finally, the sixth section presents the authors' conclusions.

\section{Literature review}

Upon analysis of the key driving forces behind companies' decisions of which activities should be vertically integrated, which variables affect decisions to make or buy, and what defines the boundaries of the firm, several authors cite the TCE and RBV theories as bases for defining a firm's boundaries (WILLIAMSON, 1999; MADHOK, 2002; McNALLY; GRIFFIN, 2004; JACOBIDES; WINTER, 2005; HOLCOMB; HITT, 2007; TADELIS, 2010).

\subsection{Transaction Cost Economics (TCE)}

In Coase's seminal work The Nature of the Firm (1937), the author examines why firms exist in a specialized exchange economy. For Coase (1937), the distinguishing purpose of firms is to replace coordination through the price mechanism with coordination through the entrepreneur or manager of the firm. This substitution occurs because the price mechanism has costs, including the costs of researching relevant prices, the costs of trading, and costs associated with contract preparation. Thus, an entrepreneur, in setting up a firm, could avoid these costs, allowing transactions to migrate to the market within the firm. However, in Coase's (1937) view, the indefinite growth of a firm may result in diminishing returns for the entrepreneur, and the firm may reach a point at which the marginal cost of organizing an internal transaction is greater than the cost of transacting in the market or the cost of organizing the transaction with another entrepreneur. At this point, the firm would cease to grow.

Extending Coase's studies, Williamson (1979) described two factors that can lead to transaction costs. The first is related to limited rationality, the inability of humans are to predict all matters relating to a transaction. The second factor is the risk of 
opportunism. This occurs when one party involved in the transaction benefits from unanticipated changes in conditions surrounding the transaction (including changes in quality, technology, and market conditions of supply and demand) and, taking advantage of this situation, the stronger party requires contract modifications that bring them undue advantage.

The main characteristics of a transaction, as stated by Williamson (1979, 1999), are uncertainty, frequency of trading, and asset specificity, i.e., the extent to which investments are specific to a transaction. Analyzing TCE from the perspective of the decision to "make or buy," the theory predicts that managers will implement the organizational form that minimises transaction costs (VAN HOEK, 2000). This decision is driven by economic factors of investments in specialised assets and uncertainties (WILLIAMSON, 1996). The greater the investment in specialized assets and the greater the uncertainties surrounding a transaction, the greater the tendency to carry it inside the boundaries of the organization. In these cases, firms choose internal forms of governance with the belief that they can respond to fluctuations in the market more readily than can their suppliers (WILLIAMSON, 1985; KAUFMANN; CARTER, 2006). One risk exposed by Fine (1998) is that the firm becomes more dependent on a supplier as tacit knowledge is lost. In this case, the loss of knowledge to the supplier creates an idiosyncratic investment by him and may generate opportunistic actions.

Oliver Williamson's and Ronald Coase's theories are very relevant today, as demonstrated in the Winter 2010 issue of the renowned California Management Review (DE FIGUEIREDO JUNIOR, 2010; HERMALIN, 2010; SHAPIRO, 2010; SPILLER, 2010; TADELIS, 2010; TEECE, 2010). A number of articles in that publication detail the impacts of Oliver Williamson's studies on the 21st Century, such ideas being strongly based on Ronald Coase's writings, as follows. Spiller (2010) examines the TCE approach of Williamson in relation to a transaction cost theory of regulation; Teece (2010a) discusses its influence on management theory and practice; De Figueiredo Junior (2010) focuses on an interdisciplinary application, discussing the issue of governance and the effect of transaction cost economics on private and public organizations; and Tadelis (2010) focuses on the economic views of Williamson and Coase, the development of a transaction cost theory of the firm, and make-or-buy decisions.

The Journal of Retailing has also dedicated its September 2010 issue to Oliver Williamson and TCE, containing 11 original research articles (DAHLSTROM; NYGAARD, 2010a). In the special issue's introduction paper, Dahlstrom and Nygaard (2010a) outline TCE's contributions to marketing and related social sciences; Teece (2010b) suggests that other factors, such as capabilities, can complement the TCE approach and shows how TCE has been combined with these other factors and with the Profiting From Innovation framework to provide a more complete analytical toolkit for evaluating forward vertical integration decisions, particularly in the context of innovation; Nickerson (2010) provides a set of perspectives on Williamson's impact on the field of strategic management; and Dahlstrom and Nygaard (2010b) present potential avenues for future TCE research, focusing on research discussed throughout the special issue.

\subsection{Resource Based View (RBV)}

The literature points to Penrose's studies as the source of the RBV theory. This origin is evidenced in such works as Foss (1997), Williamson (1999), Jacobides and Winter (2005), Barney and Clark (2007) and Ifandoudas and Chapman (2009). According to Penrose (1959), a firm should be construed as an administrative structure that connects and coordinates the activities of many individuals and groups. Overall, it should be viewed as a set of productive resources. Penrose (1959) observed that the set of resources controlled by different firms could vary significantly and that, within the same industry, firms are fundamentally heterogeneous.

According to Peteraf (1993), Foss (1997) and Barney (1999), two authors, Richard Rumelt and Birger Wernerfelt, were instrumental in shaping the modern theory of resources. In Wernerfelt's (1984) analysis, the strategy of a firm should be viewed in terms of positioning its resources and not its products and markets, in contrast to Porter's (1980) analysis. The author defined resources as anything that can be perceived as a strength or weakness of a particular firm, including brands, existing internal technological expertise, trained employees, trade contracts, machinery, efficient procedures, and capital, among others. Wernerfelt (1984) was interested in defining strategies that would ensure a competitive advantage and suggested that firms should analyze the range of the current and future resources of the firm that would have an impact on their competitive advantage.

Rumelt (1984) stated that firms, at the most primitive level, might simply differ in the relative efficiency with which they extract or process homogeneous goods. However, in the absence of perfect intermediate markets for these goods, firms would have incentives to integrate. 
The question of which activities can be outsourced, based on RBV, has been systematized by Quinn and Hilmer (1994). For these authors, firms must focus their resources on a set of core competencies in which they have definite advantages over their competitors and offer unique value to their customers. In addition, the authors recommend the outsourcing of activities for which the firm has no critical strategic need or special skills.

According to Teece (1986), if outsourcing exposes the firm to a leakage of proprietary information (i.e., knowledge that is not patentable), then the firm will take self-protective measures to reduce the loss of such knowledge. Goods and services can be contracted out in a regime in which proprietary knowledge is secure. Otherwise, they will be internally conducted within the firm. According to liebeskind (1996), the internal mechanisms that protect the firms' knowledge are superior to those present when contracting between firms.

\subsection{Definition of a Firm's Boundaries based on TCE and RBV Analysis}

TCE creates a definite approach to defining the boundaries of a firm (GEYSKENS; STEENKAMP; KUMAR, 2006; TAN; MAHONEY, 2006). However, according to Barney and Clark (2007), RBV provides three additions to help firms in the strategic decision of which activities should be conducted within its boundaries. These additions are as follows: 1 ) The firm does not have all of the resources it needs to compete successfully with other firms, 2) It is very difficult, in terms of costs to the firm, to create within itself an indispensable resource for its success, and 3) it is very difficult, in terms of costs, for a firm that does not have a resource that is essential for its success to acquire it by buying a firm that already owns the resource. When one of these three conditions occurs, a decision to outsource based on transaction costs may lead the firm to jeopardize its competitive success (BARNEY; CLARK, 2007).

The decision to outsource an activity should focus on economic factors, while integrating the concepts of transaction costs and core competencies (WILLIAMSON, 1979, 1985). According to this author, the asset's specificity is the most significant feature of the transaction in defining the firm's boundaries. Following the RBV concept, the notion of core competencies determines the boundaries of firms. According to Arnold (2000), the approaches to outsourcing dictated by TCE and RBV complement each other perfectly because, while TCE is a short-term approach based solely on costs, RBV adds a long-term perspective and includes strategic importance as one of the qualities of the transaction.

Transaction costs and capabilities are fundamentally intertwined in determining the vertical scope of firms (JACOBIDES; WINTER, 2005). They argue that the presence of different capabilities among firms is a necessary condition for vertical integration and that a reduction in transaction costs leads to specialization only if the capabilities along the value chain are heterogeneous. According to them, determination of a firm's boundaries in the short run is made by comparing its capabilities with the capabilities available in firms in the market. Thus, if the firms differ in their abilities, a reduction in transaction costs will allow significant expertise to be gained. On the other hand, if all firms are similar, the same reduction in transaction costs will not promote specialization and disintegration.

According to Mayer and Salomon (2006), TCE is fundamentally concerned with the characteristics of a transaction while keeping the firm's capabilities constant, thereby missing an analysis of how differences in the capabilities of firms influence transaction governance. The authors address ways in which RBV can complement the standard TCE approach in defining the structures of governance. Mayer and Salomon's (2006) studies are based on the assumption that technological capabilities (or lack thereof) are an important consideration when firms make governance decisions.

Holcomb and Hitt (2007) proposed a theoretical model for strategic outsourcing that includes aspects of TCE and RBV theory. The TCE arguments for outsourcing were based on specific assets, a small number of suppliers, and technological uncertainty. The RBV arguments were based on complementarity of skills, related strategies, relational mechanisms for building skills, and cooperative experience. For these authors, TCE considers the boundaries of firms to be points from which they relinquish control over access and use of resources, whereas the RBV perspective on outsourcing allows firms to build bridges across boundaries, enabling access to intermediate market skills, which are subsequently distributed along the firms' value chains. Holcomb and Hitt (2007) have stated that access to intermediate market skills allows firms to increase their value more sharply than through cost savings associated with the use of more efficient governance mechanisms.

This study contributes an empirical analysis, as suggested by Coase (1991) and Armstrong and Shimizu (2007), to the understanding of this complex phenomenon of outsourcing based on the TCE and RBV theories. The next section provides details about the research methods used. 


\section{Research methods}

An empirical analysis of the Brazilian instant coffee industry using case studies was instrumental to this research. This qualitative approach was justified because outsourcing is a contemporary phenomenon having complex and dependent interrelationships in the context in which it occurs (YIN, 2009).

Both TCE and RBV were applied at the firm level (MADHOK, 2002). As these theories are the basis for the present outsourcing study, the research unit chosen was the firm. The multiple case study strategy was used because it allowed us to observe the replication of results throughout the cases and then assess the theoretical frameworks explained by the RBV and TCE theories. The instant coffee industry in Brazil consists of approximately 20 active exporters. Within this population, the six largest companies by export volume were selected. Together, these exporters accounted for almost 95\% of the volume exported (ASSOCIAÇÃO..., 2009).

In a study of multiple cases, the reliability depends on a well-designed research protocol (CRESWELL, 2007; YIN, 2009). The first step of the protocol required the selection of interviewees. Because the outsourcing decision is perceived as a strategic activity in organizations (GRANT, 2005; ELLRAM; TATE; BILLINGTON, 2008), it was decided that the interviews should be conducted with a representative of the firms' strategic leadership team (MINTZBERG, 1979). The second step was to determine the questions to be used in the interviews, which were divided into four blocks. The first block of questions explored the context in which the firm operated; the second was aimed at understanding the core competencies of the firm; and the last two blocks focused on questions concerning outsourcing (i.e., the reasons for outsourcing, drivers used, and in what amounts specific activities were outsourced). The activities chosen to analyze outsourcing were based on Quelin and Duhamel (2003) and adapted to the instant coffee industry. A pilot test of the interview was conducted before the field survey with a specialist in the instant coffee industry, as suggested by Creswell (2007) for refinement of the interview and questions.

As any finding or conclusion in a case study is more convincing and accurate if it is based on several different sources of information, following a corroboratory mode (YIN, 2009), this research used multiple data sources. Data were gathered during 2010 and 2011 utilizing face-to-face interviews with the senior executives of the six chosen firms. These interviews lasted between two and four hours and were followed by in loco visits for direct observation. Triangulation was achieved by comparing the interview responses with the observations from the on-site visit. A member checking process was also conducted with the same senior executives to validate the researchers' findings and analysis, as recommended by Bloor (1997). This was accomplished by showing the data analysis to the participants, allowing them to evaluate and provide feedback on the accuracy of the researchers' understanding.

According to Yin (2009), research propositions should be formulated at the design phase to guide the research and thus help to define what should be examined. In this work, six propositions were used, with three of them based on TCE and the remaining three on RBV, as follows:

Propositions based on TCE:

P1 - A firm outsources activities when the transaction is subject to non-idiosyncratic investments and is recurrent (WILLIAMSON, 1985; QUELIN, 2002; ELLRAM; TATE; BILLINGTON, 2008);

P2 - A firm uses internal forms of governance when the transaction is subject to idiosyncratic asset investment (WILLIAMSON, 1985; GROVER; MALHOTRA, 2003);

P3 - Increasing levels of contractual uncertainty lead to increased use of internal forms of governance (OSBORN; BAUGHN, 1990; KAUFMANN; CARTER, 2006).

Propositions based on RBV:

P4 - A firm outsources activities when it is weak in the resources required (MAYER; SALOMON, 2006; BARTHELEMY, 2007);

P5 - A firm uses internal forms of governance when the resources required are core competencies (PRAHALAD; HAMEL, 1990; QUINN; HILMER, 1994; FINE, 1998);

P6 - A firm uses internal forms of governance when there is strategic or proprietary knowledge to be preserved (TEECE, 1986; LIEBESKIND, 1996).

This study consisted of an empirical analysis of the instant coffee industry in Brazil, which is mature, characterized by small profit margins, and intensely focused on operational efficiency and cost reduction. The findings in industries with distinct characteristics should be used carefully because the variables associated with risk, among others, may have different natures and result in different strategic drivers.

This research is also limited by the perspectives of the senior executives of the chosen firms. Thoughts on outsourcing may vary according to the operational or management level of firms. Therefore, it could be beneficial to obtain views on outsourcing at various organizational levels. However, as the focus of this paper is on how outsourcing decisions are perceived as 
a strategic activity within firms, the senior executives' opinions are the most important.

\section{Multiple case studies}

Coffee is produced on 330,000 farms in Brazil, covering approximately 2.7 million hectares and generating about eight million direct and indirect jobs. Brazil produces an annual average of 38 million $60 \mathrm{~kg}$ bags of green coffee, representing approximately 31\% of world production (INTERNATIONAL..., 2009). Of the total number of bags produced in Brazil, approximately 3.3 million are destined for the production of instant coffee.

The supply chain for instant coffee is composed of, in a simplified form, the producers of raw the material (green coffee), the instant coffee manufacturers, and retailers and wholesalers. The retailers and wholesalers resell their products to the final consumer. Producers of soluble coffee can sell their products to other intermediate industries that use instant coffee as their raw material. A schematic representation of this supply chain is shown in Figure 1. Approximately $80 \%$ of total revenues for this industry in Brazil originate from export sales (FERREIRA, 2013; ASSOCIAÇÃO..., 2013).

This empirical study focuses on six firms that operate in the instant coffee market. Five firms are producers and exporters of instant coffee, and one firm does not include instant coffee manufacturing in its business. Following the export criteria described in the research methods, the six firms studied were among the market's primary firms.

The selected firms have diverse origins. Two firms are publicly traded and Brazilian. Another two are multinational, based on Asian and European capital, and are publicly traded at their origin. The remaining firms are privately held, one being Brazilian and one European.

Firm A has an extensive product line, including its own strong brands, and the firm runs all of the production processes. It has been in the market for more than 40 years, allowing for a long-term view of the impact of economic cycles on the company.
Firm B is similar to firm A, except that the controlling interest belongs to a multinational company. In this case, it was possible to examine the impact of economic cycles on the firm. Firm $B$ has embraced vertical initiatives throughout its history, providing for an interesting analysis of its successes and failures.

Firm $\mathrm{C}$ belongs to a large multinational company and owns one of the world's leading brands of instant coffee. It stands out from the other firms because it has an engineering capability within its production processes, which allows it to develop its own instant coffee manufacturing processes.

Firm D is a Brazilian firm, although its capital is of European origin, and the firm focuses on the bulk production of instant coffee and coffee extract to serve other industries. The clients of firm D are usually other firms, who are responsible for the final packaging, marketing, and branding, among other processes.

Firm E has focused primarily on a core competency, the sale of instant coffee, while outsourcing most of its operations, including instant coffee production. The firm does not sell products under its own brand and provides products in various packaging with the client's brand in either bulk or ready-for-consumption forms.

Firm $\mathrm{F}$ is the polar opposite of firm E. Firm $\mathrm{F}$ focuses its efforts on production, while delegating virtually all other activities in its value chain to others. It sells instant coffee in various types of packaging and has no label. It produces only for other firms, who specify the product to be produced and in what packaging it should be placed.

Firms $\mathrm{E}$ and $\mathrm{F}$ are involved in a strategic alliance: Any coffee purchased by firm $\mathrm{E}$ is manufactured by firm F, which represents the largest part of the production of the latter. The contacts between firms $E$ and $F$ occur several times a day, involving all levels of the two firms. As the structures of the two firms are in constant contact, any anomaly in the relationship can be detected and dealt with in the hierarchical structures of the two firms.

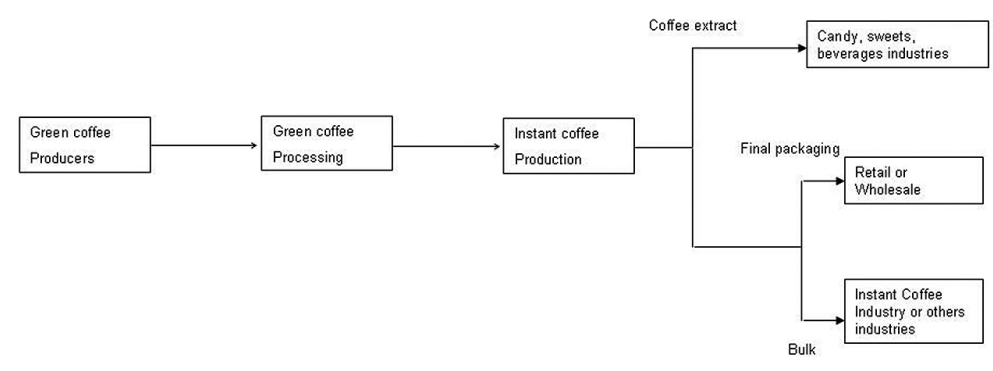

Figure 1. Instant coffee industry supply chain. 


\section{Results and discussion}

In this section, we analyze the above multiple case studies to identify patterns that explain the reasons why firms outsource activities. Exhibit 1 shows the activities that were outsourced in the firms and their key motivators: economic efficiency and possession of low skills compared to the market. Activities that have been completely outsourced are highlighted in grey, those not highlighted have been partially outsourced.

We observe from Exhibit 1 that firms that have a strategic guideline for outsourcing (C, E, and F) show a more marked degree of outsourcing than companies that do not have a strategic guideline for outsourcing. According to Porter (1985) and Grant
(2005), the definition of which activities should be carried out internally and which should be outsourced is part of strategic planning.

In the analysis of outsourcing, it is observed that economic efficiency in transactions (or in a more common form, cost reduction) was the major reason for outsourcing activities and is responsible in $87 \%$ of cases. In an industry with low margins such as instant coffee, the issue of cost reduction is key to the continuation of the business. Low skills were the second reason for outsourcing activities, and these appeared prominently in the area of marketing.

Figure 2 shows the degree of outsourcing activity among the firms studied. All activities in the value chain of the instant coffee firms studied were, to a greater

Exhibit 1. Activities outsourced in the firms and their key motivators.

\begin{tabular}{|c|c|c|c|c|c|c|}
\hline Activity & Firm A & Firm B & Firm C & Firm D & Firm E & Firm F \\
\hline Finance & & & & & & $\begin{array}{l}\text { economic } \\
\text { efficiency }\end{array}$ \\
\hline Security & $\begin{array}{l}\text { economic } \\
\text { efficiency }\end{array}$ & $\begin{array}{l}\text { economic } \\
\text { efficiency }\end{array}$ & $\begin{array}{l}\text { economic } \\
\text { efficiency }\end{array}$ & & $\begin{array}{l}\text { economic } \\
\text { efficiency }\end{array}$ & $\begin{array}{l}\text { economic } \\
\text { efficiency }\end{array}$ \\
\hline Instant coffee production & & & & & $\begin{array}{l}\text { economic } \\
\text { efficiency }\end{array}$ & \\
\hline Payroll & & & & & $\begin{array}{l}\text { economic } \\
\text { efficiency }\end{array}$ & $\begin{array}{l}\text { economic } \\
\text { efficiency }\end{array}$ \\
\hline Waste management & & $\begin{array}{l}\text { economic } \\
\text { efficiency }\end{array}$ & $\begin{array}{l}\text { economic } \\
\text { efficiency }\end{array}$ & & $\begin{array}{l}\text { economic } \\
\text { efficiency }\end{array}$ & \\
\hline Laboratory analysis & & & & & $\begin{array}{l}\text { economic } \\
\text { efficiency }\end{array}$ & \\
\hline Marketing & low skills & low skills & low skills & low skills & low skills & $\begin{array}{l}\text { economic } \\
\text { efficiency }\end{array}$ \\
\hline After sales services & & & & & & $\begin{array}{l}\text { economic } \\
\text { efficiency }\end{array}$ \\
\hline Information Technology & & & $\begin{array}{l}\text { economic } \\
\text { efficiency }\end{array}$ & & & $\begin{array}{l}\text { economic } \\
\text { efficiency }\end{array}$ \\
\hline Fluids, vapor, heat & & & $\begin{array}{l}\text { economic } \\
\text { efficiency }\end{array}$ & & $\begin{array}{l}\text { economic } \\
\text { efficiency }\end{array}$ & low skills \\
\hline Industrial Cleaning & & $\begin{array}{l}\text { economic } \\
\text { efficiency }\end{array}$ & $\begin{array}{l}\text { economic } \\
\text { efficiency }\end{array}$ & & $\begin{array}{l}\text { economic } \\
\text { efficiency }\end{array}$ & \\
\hline Sales Force & & & $\begin{array}{l}\text { economic } \\
\text { efficiency }\end{array}$ & & & $\begin{array}{l}\text { economic } \\
\text { efficiency }\end{array}$ \\
\hline Research and Development & & & & & $\begin{array}{l}\text { economic } \\
\text { efficiency }\end{array}$ & \\
\hline Industrial maintenance & low skills & & & & $\begin{array}{l}\text { economic } \\
\text { efficiency }\end{array}$ & \\
\hline Energy & $\begin{array}{l}\text { economic } \\
\text { efficiency }\end{array}$ & $\begin{array}{l}\text { economic } \\
\text { efficiency }\end{array}$ & $\begin{array}{l}\text { economic } \\
\text { efficiency }\end{array}$ & $\begin{array}{l}\text { economic } \\
\text { efficiency }\end{array}$ & $\begin{array}{l}\text { economic } \\
\text { efficiency }\end{array}$ & $\begin{array}{l}\text { economic } \\
\text { efficiency }\end{array}$ \\
\hline Support Services & $\begin{array}{l}\text { economic } \\
\text { efficiency }\end{array}$ & $\begin{array}{l}\text { economic } \\
\text { efficiency }\end{array}$ & $\begin{array}{l}\text { economic } \\
\text { efficiency }\end{array}$ & & $\begin{array}{l}\text { economic } \\
\text { efficiency }\end{array}$ & $\begin{array}{l}\text { economic } \\
\text { efficiency }\end{array}$ \\
\hline Accounting & & & & & $\begin{array}{l}\text { economic } \\
\text { efficiency }\end{array}$ & \\
\hline Recruitment and selection & & $\begin{array}{l}\text { economic } \\
\text { efficiency }\end{array}$ & $\begin{array}{l}\text { economic } \\
\text { efficiency }\end{array}$ & & $\begin{array}{l}\text { economic } \\
\text { efficiency }\end{array}$ & $\begin{array}{l}\text { economic } \\
\text { efficiency }\end{array}$ \\
\hline Logistics & $\begin{array}{l}\text { economic } \\
\text { efficiency }\end{array}$ & low skills & $\begin{array}{l}\text { economic } \\
\text { efficiency }\end{array}$ & $\begin{array}{l}\text { economic } \\
\text { efficiency }\end{array}$ & $\begin{array}{l}\text { economic } \\
\text { efficiency }\end{array}$ & $\begin{array}{l}\text { economic } \\
\text { efficiency }\end{array}$ \\
\hline Telecommunication & $\begin{array}{l}\text { economic } \\
\text { efficiency }\end{array}$ & & $\begin{array}{l}\text { economic } \\
\text { efficiency }\end{array}$ & $\begin{array}{l}\text { economic } \\
\text { efficiency }\end{array}$ & $\begin{array}{l}\text { economic } \\
\text { efficiency }\end{array}$ & $\begin{array}{l}\text { economic } \\
\text { efficiency }\end{array}$ \\
\hline Purchasing & & & $\begin{array}{l}\text { economic } \\
\text { efficiency }\end{array}$ & & & $\begin{array}{l}\text { economic } \\
\text { efficiency }\end{array}$ \\
\hline
\end{tabular}


or lesser extent, outsourced. Of the primary activities, logistics and marketing had the highest degree of outsourcing, whereas sales, after-sale services, and instant coffee production were less outsourced. Of the support activities, the case studies indicate that energy, support services, telecommunications, and security are almost completely outsourced, whereas finance, research and development, purchasing, IT, and accounting have a rather low degree of outsourcing.

Several activities that are characterized by low outsourcing (total and partial) are analyzed based on the results shown in Exhibit 2, where each activity is associated with the reason for not being outsourced (core competency, to preserve strategic information, strong competence, not studied, and high uncertainty).

From the total of 60 observations recorded in Exhibit 2, seven were outsourced and, therefore, excluded from the calculation. From this exhibit, we can deduce that the main reason for firms to use internal forms of governance (hierarchies) is that these activities are related to their core competencies $(37.7 \%)$ and are, therefore, not outsourced. This corroborates with the RBV criteria, which indicate that activities based on core competencies should not be outsourced (PRAHALAD; HAMEL, 1990; QUINN; HILMER, 1994).

The assumption that internal skills are stronger than external skills (and so are better implemented hierarchically) was the second most important reason for the decision not to outsource (26.4\%). In this sense, firms do not see the internal competencies as constants when they analyze a transaction based on TCE factors (MAYER; SALOMON, 2006).

The issue of protection of internal information (13.2\%) is linked to existing knowledge within firms and is usually linked to core competencies. Finally, the uncertainties of outsourcing (7.5\%) are linked to impacts on the firm as a whole if there is uncertainty regarding the supplier's ability to perform assignments well.

The outsourcing of some activities had not been analyzed by the firms (15.1\%). For example, firm $D$ does not have a strategy for outsourcing. Another pattern observed was the low outsourcing of information technology (IT) activities, with the main reason being fear of sensitive information leakage.

Six propositions on outsourcing were made in this article (see the Research Methods section), and these were compared with each of the six cases studied.

Proposition P1 (A firm outsources activities when the transaction is subject to non-idiosyncratic investments and is recurrent) received partial support in all cases. In the firms studied, the search for economic efficiency was conditioned by the characteristics of the supplier market, specifically a comparison between internal performance and the performance

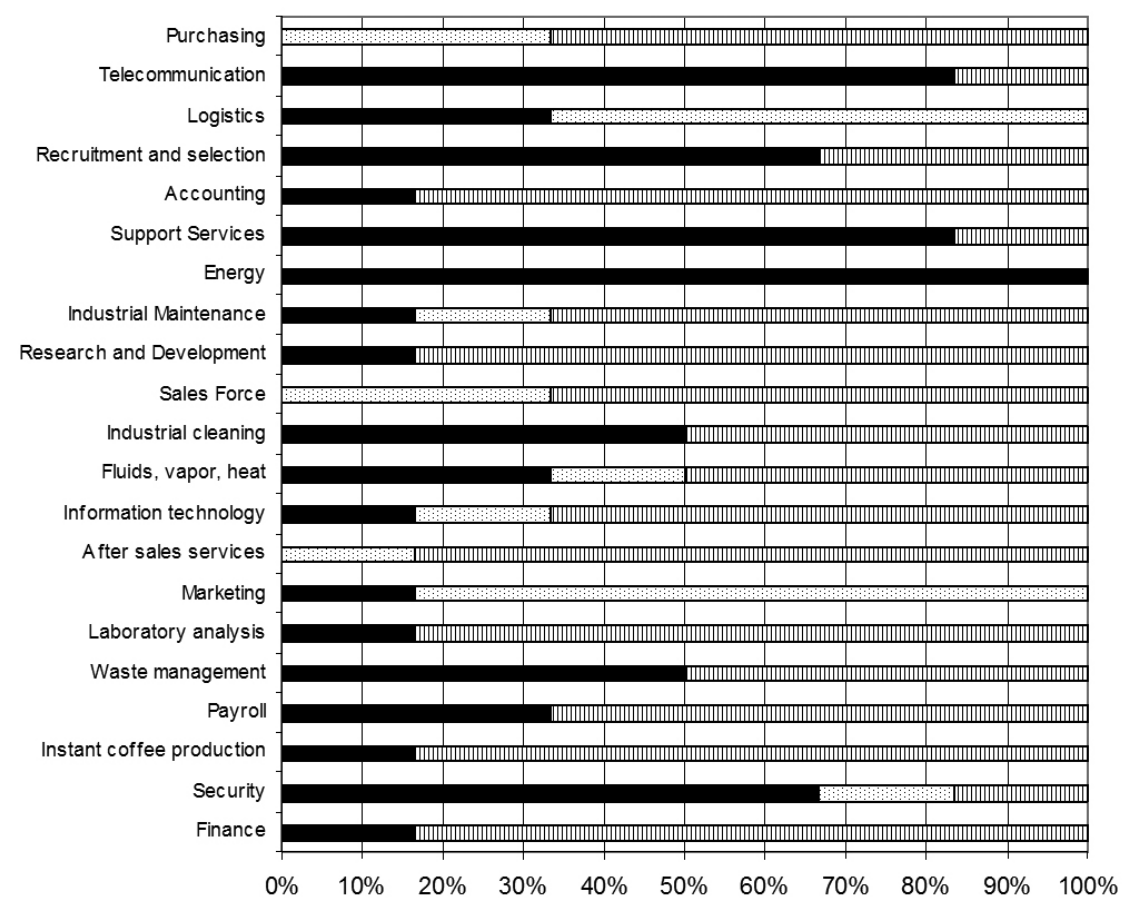

- Outsourced

$\square$ Partially Outsourced

mot Outsourced

Figure 2. Percentage of outsourcing in each activity within the instant coffee firms. 
Exhibit 2. Low outsourcing activities vs. strategic drivers.

\begin{tabular}{|c|c|c|c|c|c|c|}
\hline Activity & Firm A & Firm B & Firm C & Firm D & Firm E & Firm F \\
\hline Finance & not studied & not studied & $\begin{array}{c}\text { strong } \\
\text { competence }\end{array}$ & not studied & core competency & \\
\hline $\begin{array}{l}\text { Instant coffee } \\
\text { production }\end{array}$ & core competency & core competency & core competency & core competency & & core competency \\
\hline $\begin{array}{l}\text { Laboratory } \\
\text { analysis }\end{array}$ & core competency & core competency & $\begin{array}{l}\text { to preserve } \\
\text { strategic } \\
\text { information }\end{array}$ & not studied & & $\begin{array}{c}\text { strong } \\
\text { competence }\end{array}$ \\
\hline After sales services & core competency & core competency & core competency & not studied & core competency & not studied \\
\hline $\begin{array}{l}\text { Information } \\
\text { technology }\end{array}$ & $\begin{array}{c}\text { to preserve } \\
\text { strategic } \\
\text { information }\end{array}$ & $\begin{array}{c}\text { to preserve } \\
\text { strategic } \\
\text { information }\end{array}$ & $\begin{array}{c}\text { to preserve } \\
\text { strategic } \\
\text { information }\end{array}$ & $\begin{array}{l}\text { to preserve } \\
\text { strategic } \\
\text { information }\end{array}$ & $\begin{array}{c}\text { to preserve } \\
\text { strategic } \\
\text { information }\end{array}$ & \\
\hline Sales force & core competency & core competency & $\begin{array}{c}\text { strong } \\
\text { competence }\end{array}$ & not studied & core competency & $\begin{array}{c}\text { strong } \\
\text { competence }\end{array}$ \\
\hline $\begin{array}{l}\text { Research and } \\
\text { Development }\end{array}$ & core competency & core competency & core competency & core competency & & $\begin{array}{c}\text { strong } \\
\text { competence }\end{array}$ \\
\hline $\begin{array}{l}\text { Industrial } \\
\text { maintenance }\end{array}$ & high uncertainty & $\begin{array}{c}\text { strong } \\
\text { competence }\end{array}$ & $\begin{array}{l}\text { to preserve } \\
\text { strategic } \\
\text { information }\end{array}$ & $\begin{array}{c}\text { strong } \\
\text { competence }\end{array}$ & & $\begin{array}{c}\text { strong } \\
\text { competence }\end{array}$ \\
\hline Accounting & high uncertainty & high uncertainty & $\begin{array}{c}\text { strong } \\
\text { competence }\end{array}$ & not studied & & high uncertainty \\
\hline Purchasing & core competency & $\begin{array}{c}\text { strong } \\
\text { competence }\end{array}$ & $\begin{array}{c}\text { strong } \\
\text { competence }\end{array}$ & $\begin{array}{c}\text { strong } \\
\text { competence }\end{array}$ & $\begin{array}{c}\text { strong } \\
\text { competence }\end{array}$ & $\begin{array}{c}\text { strong } \\
\text { competence }\end{array}$ \\
\hline
\end{tabular}

of the supplier market. If the performance offered in the market was not equal to or better than the internal performance, it was not outsourced, even if cost savings could be achieved. Thus, outsourcing is not only the result of transaction costs but also of existing resources in the firm and supplier markets (MAYER; SALOMON, 2006). In the firms analyzed, the skills were compared not only with respect to technological aspects but also with respect to operational and managerial aspects, contrary to the emphasis of the authors. Thus, when firms had stronger competencies than the market, the activities were not outsourced. This was confirmed in several firms, but firms $D$ and $F$ are worth noting. These firms had no qualified suppliers in various activities because of their inland locations. Therefore, even when they want to outsource an activity, this outsourcing is hindered by the poor competence of local suppliers.

Proposition P2 (A firm uses internal forms of governance when the transaction is subject to investments in idiosyncratic assets) also received partial support. Most of the idiosyncratic investments observed were human resources. These investments were not considered to be a great loss if the contractual relations were interrupted. Another important issue raised by TCE is the opportunism that can arise when making idiosyncratic investments. This can lead to extra costs for the firm and, therefore, these activities should not be outsourced. In cases A, B, E, and F, no significant costs arising from the opportunism of parties involved in transactions were observed where idiosyncratic investments were made. In addition, the firms in the case studies created governance structures to mitigate opportunism risks in business relationships between firms and their suppliers, as when firms A, $B$, and $E$ outsourced the manufacture of instant coffee. Firms $\mathrm{E}$ and $\mathrm{F}$ were involved in a strategic alliance that also led to a mitigation of the risks of opportunism in the relationship between the firms.

Proposition P3 (Rising levels of contractual uncertainty lead to increased use of internal forms of governance) was supported every time it occurred in the cases studied. It is noteworthy that the risk issues associated with transactions are highlighted in the literature (WILLIAMSON, 1985; ELLRAM; TATE; BILLINGTON, 2008). The main risk that was apparent in the firms was the inability to measure a supplier's performance. The activities of waste management and accounting, which are widely available on the market, were not outsourced because the risk of failure by the supplier could result in costs not only for these transactions but also for all of the firms' other transactions. One example was the case of waste treatment in firms $A$ and D. Both have factories that are located in urban centers. A failure in the disposal of industrial waste generated in the factory can lead to disqualification and fines, which would affect all other activities of the firm.

Proposition P4 (A firm outsources activities when it is weak in the resources required) was supported by the case studies. The outsourcing of activities related to the development of specialized agencies 
Exhibit 3. Propositions reviewed in each case study.

\begin{tabular}{|c|c|c|c|c|c|c|}
\hline Proposition & Firm A & Firm B & Firm C & Firm D & Firm E & Firm F \\
\hline $\mathrm{P} 1$ & $\begin{array}{c}\text { partially } \\
\text { supported }\end{array}$ & $\begin{array}{c}\text { partially } \\
\text { supported }\end{array}$ & $\begin{array}{c}\text { partially } \\
\text { supported }\end{array}$ & $\begin{array}{c}\text { partially } \\
\text { supported }\end{array}$ & $\begin{array}{c}\text { partially } \\
\text { supported }\end{array}$ & $\begin{array}{c}\text { partially } \\
\text { supported }\end{array}$ \\
\hline $\mathrm{P} 2$ & $\begin{array}{c}\text { partially } \\
\text { supported }\end{array}$ & $\begin{array}{c}\text { partially } \\
\text { supported }\end{array}$ & not observed & not observed & not supported & not supported \\
\hline P3 & supported & supported & not observed & supported & not observed & supported \\
\hline P4 & supported & supported & supported & supported & supported & supported \\
\hline $\mathrm{P} 5$ & supported & supported & supported & supported & supported & supported \\
\hline P6 & supported & supported & supported & supported & supported & not observed \\
\hline
\end{tabular}

for advertising was recurrent in the cases studied. Outsourcing of industrial maintenance also appeared to be linked to the use of very specific equipment, where maintenance is normally performed by the manufacturer.

Proposition P5 (A firm uses internal forms of governance when the resources required are core competencies) was supported in all of the cases studied. In the interviews with executives, the questions regarding core competencies and strong skills were answered quickly, demonstrating that these matters had been an object of study or reflection in the six firms studied. The core competencies are performed by the firms, whereas the other activities are open to outsourcing (PRAHALAD; HAMEL, 1990; QUINN; HILMER, 1994). Thus, outsourcing is a function of core competencies, linked to the RBV assumptions, and this was observed in all of the firms analyzed.

Proposition P6 (A firm uses internal forms of governance when there is strategic or proprietary knowledge to be preserved) was supported in the situations in which it was observed. The leak of information through suppliers is perceived as a loss of competitive advantage in the instant coffee industry because it can lead to tacit or explicit information leakage concerning core competencies and can benefit competitors through third party providers, as discussed by Teece, Pisano and Shuen (1997) and Fine (1998). This issue can be observed in cases in which the outsourcing of information technology could expose the firm's secrets, principally the parameters for the manufacture of instant coffee, customer lists, and prices charged. In the presence of this possibility, the firms studied have chosen not to outsource the activity, confirming the studies of Teece (1986) and Liebeskind (1996).

Exhibit 3 summarizes the findings from the firms regarding each of the propositions considered, dividing the results into propositions that were supported, those that were partially supported, those that were not supported, and those that were not observed. The first three propositions are related to TCE and the remaining three to RBV.
In addition, accounting is not a core competency in all cases, nor do firms generally have strong skills in relation to the supply market. Thus, the activity of accounting should be outsourced according to the RBV theory (QUINN; HILMER, 1994; MAYER; SALOMON, 2006). There is, however, a risk condition for publicly traded firms inherent in the TCE if the supplier does not generate the correct accounting information. This leads to the managerial decision not to outsource the activity.

According to the TCE theory (ARNOLD, 2000), an activity should be performed within the boundaries of the firm when there are idiosyncratic investments in a transaction, thus avoiding the costs arising from possible opportunistic behavior by suppliers. However, firms A, B, and E partially or completely outsourced the manufacturing activity of instant coffee, thereby achieving the industrial capacity to meet market demand while understanding the potential costs of opportunism. This decision appears to be supported by the evidence in these cases, as the opportunism costs are not the only costs (BARNEY; CLARK, 2007). Opportunity costs also arise from an unmet market demand due to a lack of capacity that may far outweigh the costs of opportunism, leading firms A, $B$, and $E$ to outsource their manufacturing activity.

\section{Conclusions}

This paper provides a better understanding of the reasons why firms outsource activities in their value chain, combining the TCE and RBV theories in the context of the Brazilian instant coffee industry. According to our empirical research, the analyzed firms outsource activities to external suppliers with the intention of: reducing costs, improving the performance of activities necessary for conducting business by hiring suppliers, and concentrating their efforts on core competencies.

Despite the support for propositions derived from TCE and those originating from the RBV, this study argues (based on the empirical analysis of six firms) that these theories may lead to mistaken outsourcing 
decisions when used in isolation. Thus, this study determined that when analyzing outsourcing, the two theories should be used in a complementary way. The RBV theory sees the firm as a whole, comparing the resources available internally to those available in the market, seeking the few firm resources that lead to a long-term competitive advantage. In addition, RBV leads to a resource-by-resource analysis of internal performance compared to the market or to other firms while seeking the best form of governance for the activity. TCE also analyzes transaction by transaction, seeking the governance structure that minimizes transaction costs and thereby increasing the efficiency of the firm in the short term.

A first contribution of this work is the offer of a mechanism to combine both theories revealing that outsourcing activities by firms should be decided in two stages. First, at the strategic level, firms must clearly decide which activities should be performed internally, and by implication, which activities may be subject to outsourcing, in line with the policy that Porter (1985) and Grant (2005) advocate. At this strategic level, firms are studied as a whole to identify which activities are associated with the core competencies that must be performed internally (PRAHALAD; HAMEL, 1990; QUINN; HILMER, 1994). This first stage is based on the RBV theory.

After firms strategically determine the activities that will not be outsourced, they can proceed to the second stage of analysis, transaction by transaction, to determine which activities could be outsourced. At this stage, firms must compare the strengths and weaknesses of their skills with those available in the marketplace, outsourcing those activities in which the firm is not strong (POPPO; ZENGER, 1998; MAYER; SALOMON, 2006). Further, they must verify whether outsourcing can result in a loss or transfer of strategic knowledge, weakening the core competencies (TEECE, 1986; LIEBESKIND, 1996). If so, these activities should not be outsourced. Finally, they must compare the transaction costs arising from idiosyncratic investments and the uncertainties related to outsourcing with internal costs. If the outsourcing costs are higher than the bureaucratic costs, the activity should not be outsourced (WILLIAMSON, 1985; AMARAL; BILLINGTON; TSAY, 2006; ELLRAM; TATE; BILLINGTON, 2008). This second stage combines RBV and TCE theories.

The second contribution of this work relates to the costs associated with a transaction. In Williamson's studies $(1979,1985,1996)$, the costs arising from opportunism and limited rationality are relevant to the decision about outsourcing an activity. However, as Barney and Clark (2007) state, if the firm does not possess the necessary competence to perform the activity, these costs can be largely outweighed by the costs of developing the expertise internally or of acquiring it through the purchase of a firm that possesses the necessary competence. Expanding the study of Barney and Clark (2007), this study proposes that the opportunity costs can also outweigh the transaction costs (as noted in the case studies) and should be evaluated in the outsourcing analysis. These opportunity costs are related to businesses that are only likely to materialize if an activity can be outsourced. The examples in these cases were the outsourcing of the instant coffee manufacturing activity by firms $\mathrm{A}, \mathrm{B}$, and $\mathrm{E}$ to meet the demand in their markets.

From the managerial and practical point of view, top executives or entrepreneurs must exercise their leadership role by clearly defining the outsourcing strategies of the firm. The consistent message is "do not outsource activities that are strategic for the firm". To determine which activities are strategic, clear definition of a firm's core competencies are required. These skills must be internally developed and maintained. The remaining activities should be analyzed for potential outsourcing based on the indications of the TCE and RBV theories.

Another practical insight from this study is that leaders must constantly work to prevent opportunism in relationships with trading partners. By employing this approach, leaders are contributing to the stability of the firm's supply and strengthening the firm's relationships in the long run, as Selznick (1997) highlighted. This study argues that both the TCE and RBV theory should be considered when deciding which activities should be outsourced and which should be internally performed. Thus, a suggested topic for future research is the study of a model that combines the RBV view of the firm with the TCE vision of the firm, transaction by transaction. Such a study would further contribute to an understanding of the outsourcing phenomenon within firms.

\section{References}

ASSOCIAÇÃO BRASILEIRA DA INDÚSTRIA DE CAFÉ - ABIC. Exportações de Café Solúvel. Disponível em: <http:// www.abic.com.br/publique/cgi/cgilua.exe/sys/start. htm?sid=49\#82>. Acesso em: 15 abr. 2013.

ASSOCIAÇ̃̃O BRASILEIRA DA INDÚSTRIA DE CAFÉ SOLÚVEL - ABICS. Relatório de Exportador x Tipo de Café Solúvel. Disponivel em: <http://www.abics.com.br>. Acesso em: 11 mar. 2009.

AMARAL, J.; BILLINGTON, C. A.; TSAY, A. A. Safeguarding the promise of production Outsourcing. Interfaces, v. 36, n. 3, p. 220-233, 2006. http://dx.doi.org/10.1287/ inte. 1060.0210

ARMSTRONG, C. E.; SHIMIZU, K. A review of approaches to empirical research on the Resource-Based View of the firm. Journal of Management, v. 33, n. 6, p. 959-986, 2007. http://dx.doi.org/10.1177/0149206307307645

ARNOLD, U. New dimensions of outsourcing: a combination of transaction cost economics and the core competencies 
concept. European Journal of Purchasing \& Supply Management, v. 6, n. 1, p. 23-29, 2000. http://dx.doi. org/10.1016/S0969-7012(99)00028-3

BARNEY, J. B. How a firm's capabilities affect boundary decisions. Sloan Management Review, v. 40, n. 3, p. 137145, 1999.

BARNEY, J. B.; CLARK, D. N. Resource-Based Theory: creating and sustaining competitive advantage. Oxford University Press, 2007.

BARTHELEMY, J. Strategies d'externalisation. Paris: Ed. Dunod, 2007.

BECKMAN, S. L.; ROSENFIELD, D. B. Operations Strategy. New York: McGraw-Hill Higher Education, 2008.

BLOOR, M. Techniques of Validation in Qualitative Research: A Critical Commentary. In: MILLER, G; DINGWALL, R. (Ed.). Context and Method in Qualitative Research. London: SAGE, 1997. p. 37-50. http://dx.doi. org/10.4135/9781849208758.n3

COASE, R. H. The nature of the firm. Economica, v. 4, n. 16, p. 386-405, 1937. http://dx.doi. org/10.1111/j.1468-0335.1937.tb00002.x

COASE, R. H. The institucional structure of production. Nobel Prize Lecture, 1991. Disponivel em: <http://nobelprize. org/economics/laureates/1991/coase-lecture.html>. Acesso em: 21 abr. 2006.

CRESWELL, J. W. Qualitative inquiry and research design: Choosing among five approaches. London: Sage Publications, 2007.

DABHILKAR, M.; BENGTSSON, L. Invest or divest? On the relative improvement potential in outsourcing manufacturing. Production Planning \& Control: The Management of Operations, v. 19, n. 3, p. 212-228, 2008.

DAHLSTROM, R.; NYGAARD, A. The 2009 Nobel Prize in Economics to Oliver E. Williamson: Recognition of the Influence of Transaction Cost Economics on Business Research. Journal of Retailing, v. 86, n. 3, p. 209-210, 2010a. http://dx.doi.org/10.1016/j. jretai.2010.07.003

DAHLSTROM, R.; NYGAARD, A. Epilogue: Popperian Perspectives on Transaction Cost Economics and Future Directions of Empirical Research. Journal of Retailing, v. 86, n. 3, p. 284-290, 2010b. http://dx.doi. org/10.1016/j.jretai.2010.07.010

DE FIGUEIREDO JUNIOR, R. J. P. A Tribute to Oliver Williamson: Institutions, Politics, and Non-Market Strategy. California Management Review, v. 52, n. 2, p. 123-131, 2010. http://dx.doi.org/10.1525/ cmr.2010.52.2.123

ELLRAM, L. M.; TATE, W. L.; BILLINGTON, C. Offshore outsourcing of professional services: A transaction cost economics perspective. Journal of Operations Management, v. 26, n. 2, p. 148-163, 2008. http:// dx.doi.org/10.1016/j.jom.2007.02.008

FERREIRA, C. Indústria de café solúvel amarga mais um ano de fraqueza. Valor Econômico, São Paulo, 18 jan. 2013. Caderno B, p. 14.

FINE, C. H. Clock speed: winning industry control in the age of temporary advantage. New York: Basic Books, 1998.

FOSS, N. J. Resources and strategy: a brief overview of themes and contributions. In: FOSS, N. J. (Ed.). Resources Firms and Strategies: A reader in the Resource-Based perspective. New York: Oxford University Press, 1997.
GEYSKENS, I.; STEENKAMP, J-B. E. M.; KUMAR, N. Make, buy, or ally: a transaction cost theory meta-analysis. Academy of Management Journal, v. 49, n. 3, p. 519-543, 2006. http://dx.doi.org/10.5465/AMJ.2006.21794670

GRANT, R. M. Contemporary strategy analysis. 0xford: Blackwell Publishing, 2005.

GROVER, V. R.; MALHOTRA, M. K. Transaction cost framework in operations and supply chain management research: theory and measurement. Journal of Operations Management, v. 21, p. 457-473, 2003. http://dx.doi. org/10.1016/S0272-6963(03)00040-8

HERMALIN, B. E. A Tribute to Oliver Williamson: Holdup: Implications for Investment and Organization. California Management Review, v. 52, n. 2, p. 132-137, 2010. http://dx.doi.org/10.1525/cmr.2010.52.2.132

HOLCOMB, T. R.; HITT, M. A. Toward a model of strategic outsourcing. Journal of Operations Management, v. 25, n. 2, p. 464-481, 2007. http://dx.doi.org/10.1016/j. jom.2006.05.003

HOLMSTRON, B.; ROBERTS, J. The Boundaries of the firm revisited. The Journal of Economics Perspectives, v. 12, n. 4, p. 73-94, 1998. http://dx.doi.org/10.1257/ jep.12.4.73

INTERNATIONAL COFFEE ORGANIZATION - 1CO. Historical data. 2009. Disponivel em: <http://www.ico.org/new_ historical.asp>. Acesso em: 15 jul. 2009.

IFANDOUDAS, P.; CHAPMAN, R. A practical approach to achieving Agility-a theory of constraints perspective. Production Planning \& Control: The Management of Operations, v. 20, n.8, p. 691-702, 2009.

JACOBIDES, M. G.; WINTER, S. G. The co-evolution of capabilities and transaction costs: explaning the institucional structure of production. Strategic Management Journal, v. 26, p. 395-413, 2005. http:// dx.doi.org/10.1002/smj.460

KAUFMANN, L.; CARTER, C. R. International supply relationship and non-financial performance: A comparison of U.S. and German practices. Journal of Operations Management, v. 24, p. 653-675, 2006. http:// dx.doi.org/10.1016/j.jom.2005.07.001

LIEBESKIND, J. Knowledge, strategy and the theory of the firm. Strategic Management Journal, v. 17, p. 93107, 1996.

MADHOK, A. Reassessing the fundamentals and beyond: Ronald Coase, the transaction cost and resource-base theories of the firm and the institutional structure of production. Strategic Management Journal, v. 23, p. 535-550, 2002. http://dx.doi.org/10.1002/smj.247

MAYER, K. J.; SALOMON, R. M. Capabilities, contractual hazards, and governance: integrating resource-based and transaction cost perspectives. Academy of Management Journal, v. 49, n. 5, p. 942-959, 2006. http://dx.doi. org/10.5465/AMJ.2006.22798175

McIVOR, R. The outsourcing process: strategies for evaluation and management. Cambridge: Cambridge University Press, 2005. http://dx.doi.org/10.1017/ CB09780511543425

McIVOR, R. How the transaction cost and resource-based theories of the firm inform outsourcing evaluation. Journal of Operations Management, v. 27, p. 4563, 2009. http://dx.doi.org/10.1016/j.jom.2008.03.004

McIVOR, R. Understanding the manufacturing location decision: The case for the transaction cost and capability perspectives. Journal of Supply Chain Management, 
v. 49 , n. 2, p. 23-26, 2013. http://dx.doi.org/10.1111/ jscm. 12010

McNALLY, R. C.; GRIFFIN, A. Firm and Individual Choice Drivers in Make-or-Buy Decisions: A Diminishing Role for Transaction Costs in Economics. Journal of Supply Chain Management, v. 40, n. 4, p. 4-16, 2004. http://dx.doi. org/10.1111/j.1745-493X.2004.tb00252.x

MINTZBERG, H. The Structuring of Organizations. PrenticeHall, 1979.

NICKERSON, J. Oliver Williamson and His Impact on the Field of Strategic Management. Journal of Retailing, v. 86, n. 3, p. 270-276, 2010. http://dx.doi.org/10.1016/j. jretai.2010.07.007

OSBORN, R.; BAUGHN, C. Forms of interorganizational governance for multinational alliances. Academy of Management Journal, v. 33, n. 3, p. 503-520, 1990. http://dx.doi.org/10.2307/256578

PENROSE, E. The theory of the growth of the firm. New York: Wiley, 1959.

PETERAF, M. A. The Cornerstones of Competitive Advantage: A Resource-Based View. Strategic Management Journal, v. 14, p. 179-188, 1993. http://dx.doi.org/10.1002/ smj.4250140303

POPPO, L.; ZENGER, T. Testing alternative theories of the firm: Transaction cost, knowledge-based, and measurement explanations for make-or-buy decisions in information services. Strategic Management Journal, v. 19, p. 853-877, 1998. http://dx.doi.org/10.1002/ (S1C1) 1097-0266(199809) 19:9\%3C853::AlD SMJ977\%3E3.0.CO;2-B

PORTER, M. E. Competitive strategy. New York: Free Press, 1980.

PORTER, M. E. Competitive advantage: creating and sustaining superior performance. New York: Free Press, 1985.

PRAHALAD, C. K.; HAMEL, G. The core competence of the corporation. Harvard Business Review, v. 68, n. 3, p. 7991, 1990.

QUELIN, B. Les frontières de la firme. Paris: Economica, 2002.

QUELIN, B.; DUHAMEL, F. Bringing together strategic outsourcing and corporate strategy: outsourcing motives and risks. European Management Journal, v. 21, n. 5, p. 647-661, 2003. http://dx.doi.org/10.1016/S02632373(03)00113-0

QUINN, J. B.; HILMER, F. G. Strategic outsourcing. Sloan Management Review, p. 43-55, 1994.

RUMELT, R. P. Toward a strategic theory of the firm. In: LAMB, R. B. (Ed.). Competitive Strategic Management. Englewood Cliffs: Prentice-Hall, 1984. p. 556-570.

SELZNICK, P. Leadership in Administration, 1957. In: FOSS, N. J. (Ed.). Resources firms and strategies: a reader in the Resource-Based perspective. New York: Oxford University Press, 1997.

SHAPIRO, C. A Tribute to Oliver Williamson: Antitrust Economics. California Management Review, v. 52, n. 2, p. 138-146, 2010. http://dx.doi.org/10.1525/ cmr.2010.52.2.138

SPILLER, P. T. A Tribute to Oliver Williamson: Regulation: a Transaction cost perspective. California Management Review, v. 52, n. 2, p. 147-158, 2010. http://dx.doi. org $/ 10.1525 / \mathrm{cmr} .2010 .52 .2 .147$

TADELIS, S. A Tribute to Oliver Williamson: Williamson's Contribution and lts Relevance to 21st Century
Capitalism. California Management Review, v. 52, n. 2, p. 159-166, 2010. http://dx.doi.org/10.1525/ cmr.2010.52.2.159

TAN, D.; MAHONEY, J. T. Why a multinational firm chooses expatriates: integrating resource-based, agency, and transaction costs perspectives. Journal of Management Studies, v. 43, n. 3, p. 457-484, 2006. http://dx.doi. org/10.1111/j.1467-6486.2006.00598.x

TEECE, D. Profiting from technological innovation. Research Policy, v. 15, p. 285-305, 1986. http://dx.doi. org/10.1016/0048-7333(86)90027-2

TEECE, D. J.; PISANO, G.; SHUEN, A. Dynamic capabilities and strategic management. Strategic Management Journal, v. 18, n. 7, p. 509-533, 1997. http://dx.doi.org/10.1002/ (SICl) 1097-0266(199708) 18:7\%3C509::AlDSMJ882\%3E3.0.CO;2-Z

TEECE, D. A Tribute to Oliver Williamson: Williamson's Impact on the Theory and Practice of Management. California Management Review, v. 52, n. 2, p. 167-176, 2010a http://dx.doi.org/10.1525/cmr.2010.52.2.167

TEECE, D. Forward Integration and Innovation: Transaction Costs and Beyond. Journal of Retailing, v. 86, n. 3 , p. 277-283, 2010b. http://dx.doi.org/10.1016/j. jretai.2010.07.013

VAN HOEK, R. l. The purchasing and control of supplementary third-party logistics services. The Journal of Supply Chain Management, v. 36, n. 4, p. 14-26, 2000. http://dx.doi. $\operatorname{org} / 10.1111 / j .1745-493 X .2000 . t b 00082 . x$

VENKATESAN, R. Strategic Sourcing: To Make Or Not To Make. Harvard Business Review, p. 98-107, 1992.

VERWAAL, E.; COMMANDEUR, H.; VERBEKE, W. Value creation and value claiming in strategic outsourcing decisions: a resource contingency perspective. Journal of Management, v. 35 n. 2, p. 420-444, 2009. http://dx.doi. org/10.1177/0149206308328502

WERNERFELT, B. A Resource-Base View of the Firm. Strategic Management Journal, p. 171-180, 1984. http://dx.doi. org/10.1002/smj.4250050207

WILLIAMSON, 0. E. Transaction-cost economics: The governance of contractual relations. Journal of Economic Issues, v. 22, p. 233-261, 1979.

WILLIAMSON, 0. E. The economic institutions of capitalism New York: The Free Press, 1985.

WILLIAMSON, 0. E. The mechanisms of governance. New York: Oxford University Press, 1996.

WILLIAMSON, O. E. Strategy research: governance and competence perspectives. Strategic Management Journal, v.20,n.12,p. 1087-1108,1999.http://dx.doi.org/10.1002/ (SICl) 1097-0266(199912)20:12\%3C1087::AlDSMJ71\%3E3.0.C0;2-Z

YIN, R. K. Case study research: design and methods. Thousand Oaks: Sage, 2009.

\section{Acknowledgments}

The authors gratefully acknowledge the executives from the instant coffee company for their invaluable assistance with this research project. The authors also would like to thank the anonymous reviewers for their constructive feedback and the research agencies CAPES and CNPq for their support. 